\title{
Ages and sources of mantle eclogites: ID-TIMS U-Pb-Sr isotope systematics of clinopyroxene
}

\author{
Larry M. Heaman ${ }^{1}$, Sonja Aulbach ${ }^{2}$, Dorrit Jacob ${ }^{3}$, K.S. Viljoen ${ }^{4}$ \\ ${ }^{1}$ University of Alberta, Edmonton AB, Canada, lheaman@ualberta.ca \\ ${ }^{2}$ Goethe University, Frankfurt am Main, Germany, s.aulbach@em.uni-frankfurt.de \\ ${ }^{3}$ Macquarie University, North Ryde, Australia,dorrit.jacob@mq.edu.au \\ ${ }^{4}$ University of Johannesburg, Johannesburg,South Africa, fanusv@uj.ac.za
}

\section{Background and motivation}

Mantle eclogites form an integral, in cases dominant, part of most kimberlite-borne xenolith suites. They have been variously interpreted as representing the metamorphosed equivalents of underplated high-pressure melts or of subducted oceanic crust (Jacob 2004). However, it has proven notoriously difficult to extract meaningful age information from the radiogenic isotope systematics of mantle eclogites. In addition, clinopyroxene (cpx), a major carrier of incompatible lithophile elements, including the parent elements of most commonly used radioactive decay systems, is frequently altered. This can preclude separation of enough pristine material for accurate and precise analysis by common mass spectrometric techniques and hinders efforts to unravel the origins and evolution of mantle eclogites and to link their formation to regional or global tectonothermal events.

The advent of highly sensitive inductively coupled plasma mass spectrometers (ICPMS) combined with laser ablation (LA) devices has in recent years led to radical advances in in situ dating techniques, among them the acquisition of $\mathrm{Pb}$ isotopic compositions of $\mathrm{cpx}$ in eclogites (Schmidberger et al. 2007). Such data have yielded valuable model $\mathrm{Pb}$ isotope age constraints, but their interpretation is difficult as it is sensitive to both the choice of model $\mathrm{Pb}$ evolution curve and the assumption that cpx is essentially U-free. A survey of the literature, however, indicates that eclogitic cpx contains median $\mathrm{U}$ and $\mathrm{Pb}$ concentrations of 0.01 and $0.5 \mathrm{ppm}$, respectively, with $\mathrm{U} / \mathrm{Pb}$ of 0.02 , which can generate measurable amounts of radiogenic $\mathrm{Pb}$ over the typically billion-year histories of mantle eclogites. In order to further test the veracity of in situ cpx $\mathrm{Pb}$ and $\mathrm{Sr}$ isotope measurements, we determined the $\mathrm{U}-\mathrm{Pb}, \mathrm{Pb}-\mathrm{Pb}$ and $\mathrm{Sr}$ isotope compositions of $\mathrm{cpx}$ from three African eclogite suites by both LA-ICPMS and isotope dilution thermal ionisation mass spectrometry (ID-TIMS).

\section{Samples and Methods}

The samples form part of three well-characterised mantle eclogite suites. Two suites from southern African kimberlites (Lace and Orapa) have major- and trace-element relationships indicative of oceanic crustal protoliths (Aulbach and Viljoen 2015; unpubl. data). Some of the Lace eclogites formed in the Archaean, given highly unradiogenic $\mathrm{Pb}$ in two samples (Aulbach and Viljoen 2015), but multiple formation and/or modification ages from Proterozoic to Archaean are indicated for Orapa, based on Re-Os dating of sulphide inclusions in eclogitic diamonds (Shirey et al. 2008). Eclogites from Koidu (West African Craton) comprise two distinct suites, with low-Mg eclogites (ca. $3.4 \mathrm{Ga} \mathrm{Re-Os} \mathrm{whole} \mathrm{rock} \mathrm{age} \mathrm{array)} \mathrm{interpreted} \mathrm{as} \mathrm{subducted} \mathrm{oceanic} \mathrm{crust} \mathrm{and} \mathrm{high-Mg} \mathrm{eclogites} \mathrm{as}$ continental cumulates that foundered into the underlying lithospheric mantle (Barth et al. 2001, 2002).

In situ $\mathrm{Pb}$ isotope compositions were determined by LA-ICPMS using a NuPlasma 1 multi-collector ICPMS coupled to a $213 \mathrm{~nm}$ New Wave Nd:YAG laser system in the Canadian Center for Isotopic Microanalysis (CCIM), University of Alberta, following the procedure previously described for cpx in mantle eclogites (Schmidberger et al., 2007). In situ Sr isotope ratios were acquired in static collection mode with Faraday cups at Goethe-University Frankfurt, using the RESOlution (Resonetics) 193nm ArF Excimer Laser (CompexPro 102, Coherent) linked to a Thermo Finnigan Neptune multi-collector ICPMS, following methods outlined in Aulbach et al. (2016). Optically clean cpx separates (typically 1-2 mg) were leached $24 \mathrm{~h}$ in $\sim 6 \mathrm{M} \mathrm{HCl}$ and another $24 \mathrm{~h}$ in Millipore or MQ $\mathrm{H}_{2} \mathrm{O}$. Dry samples were weighed and spiked with a mixed ${ }^{205} \mathrm{~Pb}^{235} \mathrm{U}$ spike, followed by column chromatography to produce 
purified $\mathrm{Sr}, \mathrm{Pb}$ and $\mathrm{U}$ fractions. All ID-TIMS analyses were conducted at CCIM. The isotopic compositions of $\mathrm{U}$ and $\mathrm{Pb}$ were measured using a VG354 (Daly photomultiplier detector mode) and Thermo Triton Plus (single SEM) TIMS. Purified Sr fractions were run on a Sector 54 TIMS operating in static multi-Faraday detector mode.

\section{Preliminary Results and Discussion}

We have obtained ID-TIMS (solution) and LA-ICPMS (in situ) Pb isotopic data for most eclogite cpx samples (total of 25 xenoliths). For most xenoliths ( $n=21$ ), at least two multi-grain ( $\sim 10$ grains) cpx fractions were analysed by ID-TIMS to evaluate repeatablilty; for the majority of these (14/21) the Pb isotopic compositions agree within analytical uncertainty. Those that have variable $\mathrm{Pb}$ isotopic compositions outside analytical uncertainty reflect a multi-component $\mathrm{Pb}$ record within a single $\mathrm{cpx}$ population. ID-TIMS results for acid-leached eclogitic cpx in this study indicate a moderate range in uranium (0.004-0.369 ppm) and model Th (0.006-5.845 ppm) contents. We have evaluated the effect of an $\mathrm{HCl}$ acid-leaching treatment on the $\mathrm{Pb}$ isotopic composition of two eclogitic cpx samples. In one case the unleached cpx has $\mathrm{U}$ and Th contents and ${ }^{238} \mathrm{U} /{ }^{204} \mathrm{~Pb}$ values that are a factor of 10 higher than leached cpx, indicating the presence of labile $\mathrm{U}$ and Th. In contrast, the effect of leaching on $\mathrm{cpx} \mathrm{Pb}$ contents and $\mathrm{Pb}$ isotopic ratios is negligible ( $<1 \%$ change in compositions). Leached eclogitic cpx typically have relatively low ${ }^{238} \mathrm{U} /{ }^{204} \mathrm{~Pb}$ values $(<40 ; \mathrm{n}=41 / 46)$, however for ancient xenoliths this corresponds to a significant correction for in-growth of radiogenic $\mathrm{Pb}$ in $\mathrm{Pb}-\mathrm{Pb}$ dating studies. In some cases, variable $\mathrm{U}$ concentrations at relatively homogeneous $\mathrm{Th}$ and $\mathrm{Pb}$ contents of multiple leached aliquots suggests that some labile $\mathrm{U}$ can remain after the HCl-leaching treatment.

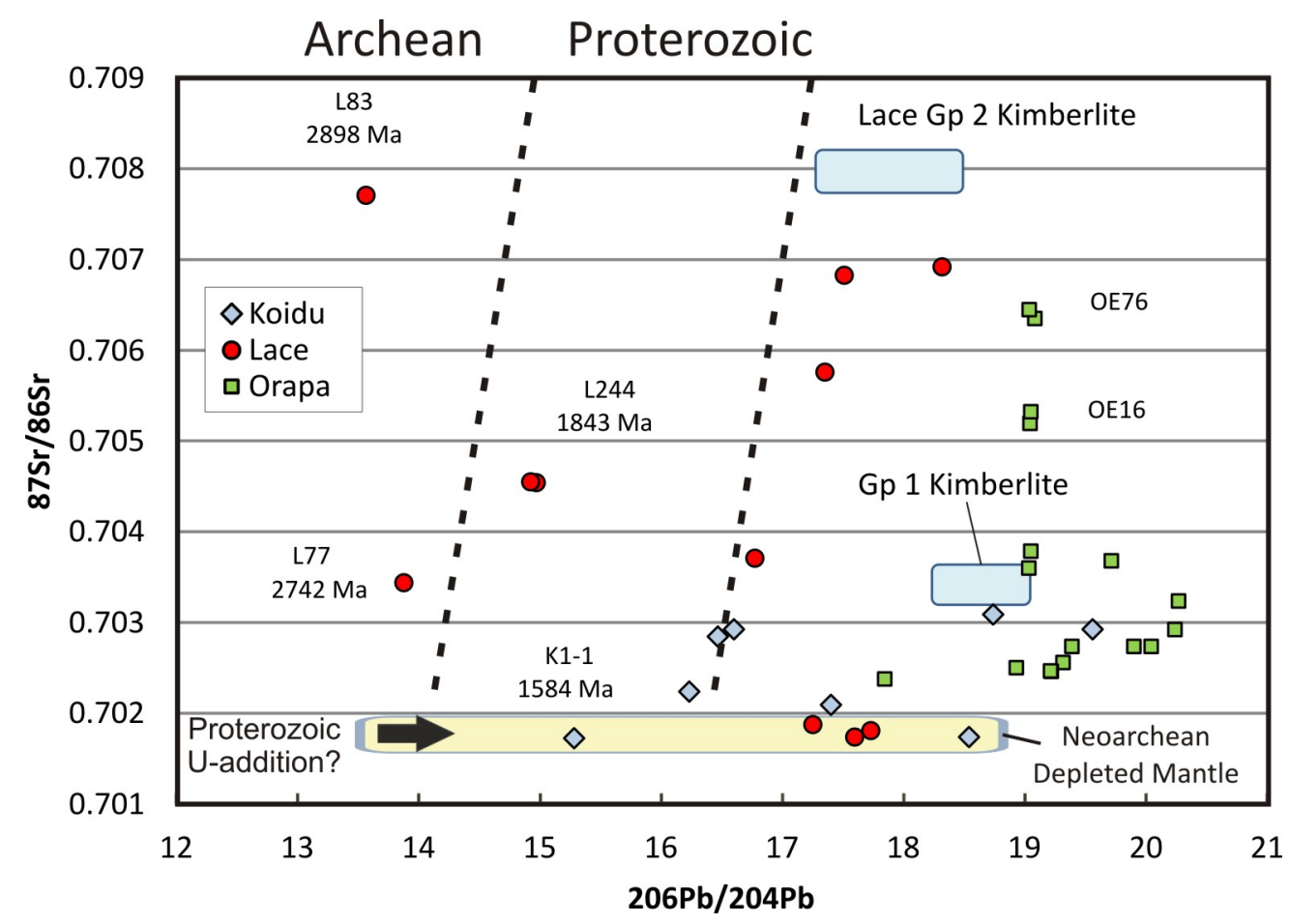

Figure 1. Measured ${ }^{87} \mathrm{Sr} /{ }^{86} \mathrm{Sr}$ versus ${ }^{206} \mathrm{~Pb} /{ }^{204} \mathrm{~Pb}$ obtained by ID-TIMS for cpx in three eclogite xenolith suites.

Preliminary results show that acid-leached eclogitic cpx with low U contents and matching in situ and solution $\mathrm{Pb}$ isotope ratios can contain a significant component of radiogenic $\mathrm{Pb}$ (up to $10 \%$ ); hence in situ $\mathrm{Pb}-\mathrm{Pb} \mathrm{cpx}$ analyses commonly do not reflect their initial $\mathrm{Pb}$ isotopic compositions, resulting in underestimated/inaccurate $\mathrm{Pb}-\mathrm{Pb}$ model ages. The ID-TIMS cpx data for Lace $\left({ }^{206} \mathrm{~Pb} /{ }^{204} \mathrm{~Pb}=13.54\right.$ 18.32), Koidu (16.25-19.56), and Orapa (17.92-20.27) eclogites define crude linear arrays on $\mathrm{Pb}-\mathrm{Pb}$ plots with Paleoproterozoic secondary isochron dates $(2.15,2.24$ and $1.80 \mathrm{Ga}$, respectively). Two cpx fractions from Lace eclogite $\mathrm{L} 83$, which have high $\mathrm{Pb}$ contents $(\sim 6 \mathrm{ppm})$, unradiogenic $\mathrm{Pb}$ isotopic 
compositions $\left({ }^{206} \mathrm{~Pb} /{ }^{204} \mathrm{~Pb}=13.57-13.52\right)$, the lowest ${ }^{238} \mathrm{U} /{ }^{204} \mathrm{~Pb}$ values (1.0-1.5), and ancient singlestage model $\mathrm{Pb}$ dates (2.90-2.84 Ga; minimum estimates for their formation) support an Archaean formation age.

All eclogite suites display a large range in ${ }^{87} \mathrm{Sr} /{ }^{86} \mathrm{Sr}$ values (Figure 1; total range is $0.7017-0.7077$ ) and there is general agreement for most samples between in situ and solution results. Several eclogites, representing examples from each suite, have Neoarchean depleted mantle-like ${ }^{87} \mathrm{Sr} /{ }^{86} \mathrm{Sr}$ values (0.7017-0.7025), consistent with a subducted oceanic lithosphere protolith. The origin of cpx with radiogenic strontium isotopic compositions is less clear. In some instances there may be cryptic metasomatism caused by the host kimberlite, some Lace eclogites have cpx compositions approaching that of the Lace kimberlite $\left({ }^{87} \mathrm{Sr} /{ }^{86} \mathrm{Sr}=0.7072-0.7084\right.$; Howarth et al. 2011). In others the compositions are more radiogenic than the host kimberlite so likely reflect metasomatic processes influencing the xenoliths prior to entrainment in kimberlite magma. An interesting feature of this study is that $\mathrm{Sr}$ and $\mathrm{Pb}$ isotopes do not always show coherent behaviour in eclogite cpx; radiogenic $\mathrm{Pb}(>>$ Depleted Mantle) is observed in samples with restricted depleted mantle-like ${ }^{87} \mathrm{Sr} /{ }^{86} \mathrm{Sr}$, perhaps due to heterogeneous contributions from various slab components, as previously suggested (Aulbach et al. 2016). Taken together, two pieces of isotopic evidence indicate that some Lace and Koidu eclogites are Archaean: 1) Unradiogenic $\mathrm{Pb}$ as described above and 2) very low ${ }^{87} \mathrm{Sr} /{ }^{86} \mathrm{Sr}$ in some xenoliths. In this scenario, the secondary isochrons recorded by Lace and Koidu xenoliths are interpreted as Palaeoproterozoic metasomatic overprint events.

Although this must be regarded as work in progress, our preliminary results confirm that the conclusions arrived at based on both the cpx $\mathrm{Pb}$ and $\mathrm{Sr}$ LA-ICPMS and ID-TIMS isotopic techniques are the same. In situ LA-ICPMS Pb-Pb isotope acquisition is a high-throughput method that provides guidance for sample targeting for the more precise yet highly time-intensive solution work. Together with in situ $\mathrm{Sr}$ isotope determination it further serves as a valuable check on the purity of the separated cpx with respect to kimberlite contamination. Finally, this study highlights that a ID-TIMS $\mathrm{U}-\mathrm{Pb}$ study of $\mathrm{cpx}$ has the potential to provide geologically meaningful minimum formation ages for mantle eclogites, as well as their source compositions and evolution.

\section{References}

Aulbach S, Gerdes A, Viljoen KS (2016) Formation of diamondiferous kyanite-eclogite in a subduction melange. Geochim Cosmochim Acta 179:156-176

Aulbach S, Viljoen KS (2015) Eclogite xenoliths from the Lace kimberlite, Kaapvaal craton: From convecting mantle source to palaeo-ocean floor and back. Earth Planet Sci Lett 431:274-286

Barth MG, Rudnick RL, Carlson RW, Horn I, McDonough WF (2002) Re-Os and U-Pb geochronological constraints on the eclogite-tonalite connection in the Archean Man Shield, West Africa. Precamb Res 118:267-283

Barth MG, Rudnick RL, Horn I, McDonough WF, Spicuzza MJ, Valley JW, Haggerty SE (2001) Geochemistry of xenolithic eclogites from West Africa, Part I: A link between low MgO eclogites and Archean crust formation. Geochim Cosmochim Acta 65(9):1499-1527

Howarth GH, Michael E, Skinner W, Prevec SA (2011) Petrology of the hypabyssal kimberlite of the Kroonstad group II kimberlite (orangeite) cluster, South Africa: Evolution of the magma within the cluster. Lithos 125:795-808

Jacob DE (2004) Nature and origin of eclogite xenoliths from kimberlites. Lithos 77(1-4):295-316

Schmidberger SS, Simonetti A, Heaman LM, Creaser RA, Whiteford S (2007) Lu-Hf, in-situ Sr and $\mathrm{Pb}$ isotope and trace element systematics for mantle eclogites from the Diavik diamond mine: Evidence for Paleoproterozoic subduction beneath the Slave craton, Canada. Earth Planet Sci Lett 254(1-2):55-68

Shirey SB, Richardson SH, Harris JW (2008) Mesoarchean to Mesoproterozoic Re-Os ages for sulfide inclusions in Orapa diamonds and implications for Kaapvaal-Zimbabwe craton development. In: 9th Int Kimb Conf, Frankfurt, Germany, Ext Abstr No. 9IKC-A-00365, 02008 